\title{
Implementation of Instrument Based on Eight Health Related Quality of Life Domains for Measuring of Willingness to Pay for Psoriasis Treatment
}

\author{
Hristo P. Dobrev ${ }^{1}$, Nikolay G. Atanasov², Donka D. Dimitrova² \\ ${ }^{1}$ Department of Dermatology and Venereology, Faculty of Medicine, Medical University of Plovdiv, Plovdiv, Bulgaria \\ 2 Department of Health Management and Health Economics, Faculty of Public Health, Medical University of Plovdiv, Plovdiv, \\ Bulgaria
}

\section{Correspondence:}

Nikolay G. Atanasov, Department of Health Management and Health Economics, Faculty of Public Health, Medical University of Plovdiv, 15A Vassil Aprilov Blvd., 4002 Plovdiv, Bulgaria E-mail: nik.atanasov@abv.bg Tel: +359885771262

Received: 26 Sep 2016 Accepted: 9 Mar 2017

Published Online: 24 Apr 2017 Published: 29 Sep 2017

Key words: willingness to pay stated preferences, psoriasis, quality of life, financial burden of disease

Citation: Dobrev HP, Atanasov NG, Dimitrova DD. Implementation of instrument based on eight health related quality of life domains for measuring of willingness to pay for psoriasis treatment.

Folia Medica 2017;59(3):326-335 doi: 10.1515/folmed-2017-0041
Background: Psoriasis vulgaris (PsV) is a chronic skin condition that has a major impact on health-related quality of life (HRQOL).

Aim: To determine the individual burden of PsV on HRQOL using willingness to pay (WTP) instrument.

Materials and methods: Fifty-one consecutive PsV patients were asked to evaluate their overall health and psoriasis affected health by visual analogue scale (VAS), and interviewed on 8 domains (physical, emotional, sleep, work, social, selfcare, intimacy, and concentration) of HRQOL and WTP for a hypothetical cure in each domain. Two additional questions proposing 6 alternatives for therapy were also asked. The analysis is performed with descriptive and frequency statistics, Mann-Whitney and Kruskal-Wallis tests.

Results: The domains ranked highly were: physical comfort (90\%), social comfort (77\%), emotional health (75\%) and work (53\%). The following tendencies concerning WTP for top four impacted domains were found: the median WTP were the highest in the top impacted domains; the younger patients were willing to pay more than the older ones; the highest median WTP amounts appear in the lowest income group; the highest median WTP is associated with smaller psoriasis affected health VAS scores. The largest proportion and number of patients $(37.3 \%$, $\mathrm{n}=19)$ stated preferences for the systemic therapy. The second preferred choice was the thalassotherapy $(29.4 \%, n=15)$.

Conclusions: The utility and reliability of the instrument based on the assessment of WTP stated preferences for 8 domains of HRQOL for evaluation the individual burden of psoriasis were strongly supported.

\section{BACKGROUND}

Psoriasis is a chronic inflammatory skin disease that affects approximately $2 \%$ of the world's population. ${ }^{1}$

Depending on localisation, type and severity of skin lesions as well as presence of joint and nail involvement, the disease may affect the patients' quality of life (QoL) in varying degrees. It is considered that QoL includes all factors that have an impact on an individual's life whereas HRQOL relates only to health aspects, including psychological, social, and physical well-being. ${ }^{2}$

Studies of the impact of psoriasis on patient's QoL most commonly use generic tools - Short Form 36 (SF-36) and EuroQoL 5D (EQ-5D), skin-specific measures - Dermatology Life Quality Index (DLQI) and SkinDex, and psoriasis - specific questionnaires and instruments - Psoriasis Index of Quality of Life (PSORIQoL), Psoriasis Disability Index (PDI), and Psoriasis Life Stress Inventory (PLSI). ${ }^{3}$

The willingness-to-pay (WTP) method is related to contingent valuation of public goods in welfare economies. ${ }^{4}$ The method was first used to value public goods in environment and transportation. ${ }^{5}$ The advantages of the contingent valuation method as a hypothetical direct elicitation method of benefits and WTP are described with its full coverage of at least three criteria as 'able to obtain option price in uncertainty', 'able to value goods not pre- 
viously available', 'able to estimate all existence class benefits'. ${ }^{6}$ Arrow, Sollow, Portney et al. have discussed some disadvantages of WTP elicitation such as: obtaining results that differ from rational choice, difficulties in identifying the boundaries of the market and respondents succumbing to their feelings and emotions about the social importance of the program or goods. ${ }^{7}$

Recently, the contingent valuation method has found its applications in health research. According to Smith R. and Sach T. the annual number of studies has increased from 3 in 1985 to 38 in 2005; the countries with the highest number of such studies are the USA, UK and Canada. Out of 265 publications on WTP reviewed between 1958 and 2005 , the majority were in the field of infectious diseases (53), followed by cancer (23) and cardiac disease (18). ${ }^{8}$ Our previous findings show that the number of articles in PubMed that include the term 'willingness to pay' in the title or in the abstract have increased rapidly since 2000 and reached its maximum in 2012 (265). ${ }^{9}$

The obtained WTP values accounting for patient preferences and benefits could be used for assessing the costs and for demand curve estimation in cost-effectiveness analysis in health. ${ }^{10-12}$

The aim of this study was to determine the individual burden of psoriasis vulgaris on health-related quality of life using willingness-to-pay instrument.

\section{MATERIALS AND METHODS}

\section{PATIENTS}

From October 2014 to June 2015, 51 consecutive patients hospitalized for psoriasis vulgaris in the Clinic of Dermatology and Venereology at St George University Hospital in Plovdiv were recruited to be interviewed. Every year between 80 and 100 patients with psoriasis are admitted to this clinic. Eligible patients were 18 years of age or older, diagnosed with psoriasis for more than two years. Patients were given a brief verbal explanation of the nature of the study and, after obtaining their informed consent, were interviewed by the first author. The interviews lasted 30 minutes on average.

\section{INSTRUMENT}

We used the instrument and procedure designed by $\mathrm{Hu}$ et al. ${ }^{13}$ that is based on a similar tool previously used in a study by Delfino et al. ${ }^{14}$ The questionnaire comprises 8 domains of health, affected by psoriasis: intimacy, physical comfort, self-care, ability to work or volunteer, ability to concentrate, emotional health, social comfort, ability to sleep ranked for being affected by psoriasis and willingness to pay any amount of money to eliminate all impairment in the affected domains. ${ }^{13,14} \mathrm{~A}$ standard procedure was followed to translate the English source version of the questionnaire into Bulgarian including forward and backward translations by independent translators fluent in English and expert assessment to reach an agreed version.

The tool also employs a visual analogue scale (VAS) to assess overall health and psoriasis affected health and open-ended questions to evaluate WTP stated-preferences. In reference to localization of the tool the answers relating to WTP and monthly household income were given in the local currency (BGN) but they are presented in the results and further discussions in EUR (after conversion using the fixed exchange rate of the Bulgarian currency in Euro, 1 EUR $=1.95583 \mathrm{BGN}$ ) and rounded to integer multiple by a hundred.

Two additional questions to those posed in the previous studies were included. The first one proposed six alternatives for a therapy: 2 for topical therapy, 2 for systemic therapy, one for physical therapy, and one for thalassotherapy as presented in Table 1.

The second question we added asked about the most important reasons for the choices of the respondents. We proposed the following options: place of therapy; therapeutic method; efficiency of the therapy; adverse effects; payment; time to wait until the start of the therapy (if any); others.

To compare results we also used two universally recognized instruments particularly applied in the field of skin decease - DLQI and EQ-5D-5L to measure the HRQOL.

Patient demographics were also collected. It should be noted that the questions relating to ethnicity, educational level, monthly household income and health insurance coverage were adapted taking into consideration the national specifics. The question on monthly household income was closeended using eight schedules, starting at EUR 100 and increasing by increments of EUR 150 to EUR 1000 , the last level being left without upper limit.

Within the frame of this study respondents were not asked about any medicinal products, devices or equipment.

\section{Statistical anAlysis}

The following statistical methods were used:

- frequencies and percentages were calculated for 
Table 1. Proposed alternatives for a therapy of psoriasis

\section{Therapy}

A. Topical therapy: once daily application of topical product at home for 30 days. The treatment is paid by the patient. The effect is slow and transitory.

B. Topical therapy: twice daily application of topical product at hospital for 10 days followed by twice daily application of topical product at home for 10 days. Only the treatment at home is paid by the patient. The effect is slow but lasts longer.

C. Systemic therapy: daily administration of oral tablets for 3 months at home. The therapy is somewhat expensive and is paid by the patient. The efficiency is $50 \%$.

D. Systemic therapy: once a week intramuscular administration of drugs for 2 weeks at hospital followed by administration of oral tablets for 6 months. Only the treatment at home is paid by the patient. It is not expensive and the efficiency is $90 \%$.

E. Physical therapy: administration of tablets and visit to a hospital 3 times a week for 1 hour over 4 weeks for radiation using a special lamp. The therapy is paid by the patient. The efficiency is $70 \%$.

F. Thalassotherapy: daily exposure to sun, sea water and marine mud at sanatorium for 3 weeks. The treatment is covered by the National Health Insurance Fund and the patient needs to wait for appointment. The efficiency is $70 \%$ patients.

categorical variables;

- Mann-Whitney (M-W) and Kruskal-Wallis (KW) tests were used to assess differences in median WTP amounts across genders, ages and household income levels;

- $\quad \chi^{2}$ tests were used to assess relationships between participants' demographics and whether they were affected by a domain or willing to pay for a cure in a domain;

- normality tests of observed variables were conducted with Shapiro-Wilk test (S-W);

- Spearman's correlation coefficient $(\rho)$ to assess correlations between variables with non-normal distribution.

All tests were considered significant at $\mathrm{P} \leq 0.05$. The data are presented as a mean \pm standard deviation, or a median and first and third quartile groups $\left(\mathrm{Q}_{1} ; \mathrm{Q}_{3}\right)$.

\section{RESULTS}

In our study we did not obtain extreme amounts for the WTP. Therefore, none of the 51 interviewees were excluded from the analysis. The major part of the study population was ethnic Bulgarians (74.5\% with $95 \%$ CI $[61.6 \% ; 87.4 \%])$. The age of participants varied in quite a wide range from 18 to 78 years with a median of 57 years. The distribution of observed population by age was not normal (S-W Sig. $<0.05)$. The demographic characteristics of the study population are shown in Table 2 .

The number of men was significantly greater than that of women $(72.5 \%$ with $95 \%$ CI $[59.3 \% ; 85.7 \%$ ] and $27.5 \%$ with $95 \%$ CI $[14.3 \% ; 40.7 \%$, respectively). The prevailing part of our study population had very low income levels: $84.3 \%$ with 95\% CI $[73.3 \% ; 95.3 \%]$ of the interviewees fell within the first two quartiles. Most of the interviewees - 46 (90.2\% with 95\% CI [81.1\%;99.3\%]) had highschool or lower education. As expected, the lower education and the relatively high mean age were associated with lower income levels in the studied sample.

We also found no significant differences between the assessment of the overall health status and health effect of psoriasis alone. Median score and those of the first quartile group of VAS were identical. The same applies to VAS means concerning overall health status and health effect of psoriasis (5.33 \pm 1.95 with $95 \%$ CI [4.78;5.88] and $5.49 \pm 1.89$ with $95 \%$ CI [4.96;6.02], respectively). Both the overall health VAS score and psoriasis VAS score had a distribution approximating the normal (S-W Sig. > 0.05).

There was a medium inverse correlation between DLQI and psoriasis VAS scores $(\rho=-0.512$; Sig. $(2$-tailed $)=0.000)$ as well as between EQ-5D-5L and psoriasis VAS scores $(\rho=-0.45$; Sig. (2-tailed) $=0.001$ ). 
Table 2. Demographic characteristics of study population

\begin{tabular}{|c|c|c|}
\hline \multirow{2}{*}{ Characteristic } & \multicolumn{2}{|c|}{ n $(\%)$ or Median $\left(Q_{1} ; Q_{3}\right)$} \\
\hline & Our contingent & Hu SW et al. study \\
\hline \multicolumn{3}{|l|}{ Age } \\
\hline 45 years & $12(23.5)$ & $18(30)$ \\
\hline$\geq 45$ years & $39(76.5)$ & $41(70)$ \\
\hline \multicolumn{3}{|l|}{ Sex } \\
\hline Male & $37(72.5)$ & $33(56)$ \\
\hline Female & $14(27.5)$ & $26(44)$ \\
\hline \multicolumn{3}{|l|}{ Ethnicity } \\
\hline Bulgarian & $38(74.5)$ & \\
\hline Turkish & $8(15.7)$ & \\
\hline Roma & $5(9.8)$ & \\
\hline \multicolumn{3}{|l|}{ Monthly household income } \\
\hline$\leq 225 €$ & $22(43.1)$ & $9(15)^{*}$ \\
\hline $225.01 €$ to $550 €$ & $21(41.2)$ & $11(19)^{*}$ \\
\hline $550.01 €$ to $850 €$ & $5(9.8)$ & $10(17)^{*}$ \\
\hline $850.01 €$ & $3(5.9)$ & $29(49)^{*}$ \\
\hline \multicolumn{3}{|l|}{ Educational attaiment level } \\
\hline High school or lower & $46(90.2)$ & $9(15)$ \\
\hline Higher education & $5(9.8)$ & $50(85)$ \\
\hline Health insurance coverage & $51(100)$ & $58(98)$ \\
\hline \multicolumn{3}{|l|}{ Employment } \\
\hline Employed & $11(21.6)$ & \\
\hline Unemployed / retired & $40(78.4)$ & \\
\hline Other diseases reported & $36(70.4)$ & $46(78)$ \\
\hline Overall Health VAS & $5(4 ; 7)$ & $7(5 ; 8)$ \\
\hline Psoriasis VAS & $5(4 ; 7)$ & $7(5 ; 8)$ \\
\hline DLQI & $14(8 ; 17)$ & \\
\hline EQ-5D-5L & $20(17 ; 26)$ & \\
\hline
\end{tabular}

* Number and relative share of patients by their annual household income in each quartile group.

The domains ranked highly (1 to 4 ) as affected HRQOL were: physical comfort (90\% with $95 \%$ CI [80.8\%;99.2\%]), social comfort (77\% with 95\% CI [64.5\%;89.5\%]), emotional health $(75 \%$ with $95 \%$ CI $[62.1 \% ; 87.9 \%])$ and work (53\% with $95 \%$ CI [38.3\%;67.7\%]) (Table 3).

The least impacted domains: 'concentration', 'intimacy' and 'self-care' are also shown in Table 3.

Median and mean amounts of WTP were the highest in the top four impacted domains and drop down in the other (Table 3).

However, the WTP amounts grouped by domains were not normally distributed, except for the reports of the smallest group of patients will- ing to pay for recovery of 'self-care'. The share of patients willing to pay for the cure of 'work' domain was considerable as it was ranked as the fourth affected domain.

We established a significant variation of WTP amounts - the minimum was reported for cure of 'intimacy' (EUR 5) and the maximum - for 'physical comfort' (EUR 2500). WTP amounts for some domains were significantly correlated. The WTP amounts for 'intimacy' and 'self-care' have got Spearman's correlation coefficient close to 1 . The WTP for 'sleep' was highly correlated with 'selfcare' $(\rho=0.883)$, 'work' $(\rho=0.852)$ with 'social comfort' $(\rho=0.667)$ (Table 4). There was a strong 
Table 3. Health domains affected by psoriasis and WTP to cure

\begin{tabular}{|c|c|c|c|c|c|}
\hline Domain & $\begin{array}{l}\text { Number and } \\
\text { share of partici- } \\
\text { pants believing } \\
\text { domain to be } \\
\text { affected } n,(\%)\end{array}$ & $\begin{array}{c}\text { Number and } \\
\text { share of } \\
\text { participants } \\
\text { WTP, n, (\%) }\end{array}$ & $\begin{array}{c}\text { Domains } \\
\text { ranked in top } \\
4 \text { as affected } \\
\text { by psoriasis, } \\
n,(\%)\end{array}$ & $\begin{array}{c}\text { WTP Median } \\
\text { Amount in } \\
\text { EUR }\left(Q_{1} ; Q_{3}\right)\end{array}$ & $\begin{array}{l}\text { Mean WTP } \pm \text { SD; } \\
95 \% \text { CI of Mean } \\
\text { in EUR }\end{array}$ \\
\hline Physical comfort & $46(90)$ & $46(90)$ & $43(84)$ & $200(100 ; 500)$ & $\begin{array}{l}359.24 \pm 450.88 \\
{[225.35 ; 493.13]}\end{array}$ \\
\hline Social comfort & $39(77)$ & $37(73)$ & $33(65)$ & $150(43 ; 300)$ & $\begin{array}{l}207.96 \pm 222.09 \\
{[134.96 ; 280.96]}\end{array}$ \\
\hline Emotional health & $38(75)$ & $37(73)$ & $32(63)$ & $250(75 ; 250)$ & $\begin{array}{c}272.64 \pm 306.27 \\
{[170.52 ; 374.75]}\end{array}$ \\
\hline Work & $27(53)$ & $26(51)$ & $29(57)$ & $300(150 ; 500)$ & $\begin{array}{c}345.74 \pm 279.49 \\
{[235.18 ; 456.30]}\end{array}$ \\
\hline Sleep & $28(55)$ & $27(53)$ & $23(45)$ & $100(50 ; 400)$ & $\begin{array}{l}230.56 \pm 249.07 \\
{[132.03 ; 329.08]}\end{array}$ \\
\hline Concentration & $22(43)$ & $20(39)$ & $23(45)$ & $100(50 ; 200)$ & $\begin{array}{l}151.90 \pm 146.76 \\
{[85.10 ; 218.71]}\end{array}$ \\
\hline Intimacy & $22(43)$ & $21(41)$ & $18(35)$ & $125(50 ; 300)$ & $\begin{array}{c}217.38 \pm 239.69 \\
{[108.28 ; 326.49]}\end{array}$ \\
\hline Self-care & $10(20)$ & $9(18)$ & $11(22)$ & $125(27,50 ; 225)$ & $\begin{array}{c}137.78 \pm 121.27 \\
{[44.56 ; 240]}\end{array}$ \\
\hline
\end{tabular}

correlation between WTP for 'social comfort' and 'emotional health' $(\rho=0.712)$. For the most affected domain 'physical comfort' participants reported WTP that was well correlated with 'emotional health' $(\rho$ $=0.583)$, 'social comfort' $(\rho=0.53)$, 'intimacy' $(\rho=0.514)$ and 'work' $(\rho=0.431)$.

WTP preferences can be affected by demographics but we found no significant differences across genders (M-W Asymp. Sig. (2-tailed) $>0.05$ for all 8 domains' WTP), household income groups (K-W Asymp. Sig. $>0.05$ for all 8 schedules) and patients with different health status in each of the 10 groups by psoriasis VAS score (K-W Asymp. Sig. $>0.05$ ). It also refers to the level of education. We didn't find statistically significant differences between WTP reported from more or less educated patients (K-W Asymp. Sig. $>0.05$ for all 8 domains' WTP). These results contrast to the WTP among three age groups (below 40; 40 to 60 ; above 60 ). We found significant difference among age groups' WTP reported for following domains: 'physical comfort', 'emotional health', 'social comfort' and 'sleep' (K-W Asymp. Sig. < $0.05)$.

The following tendencies concerning WTP for the most affected domains should be noted: younger patients median WTP was bigger than in the older ones (Fig. 1); the highest median WTP amounts appear in the lowest income groups (Fig. 2); the highest median WTP amounts are associated with worsening the health condition affected by the psoriasis.

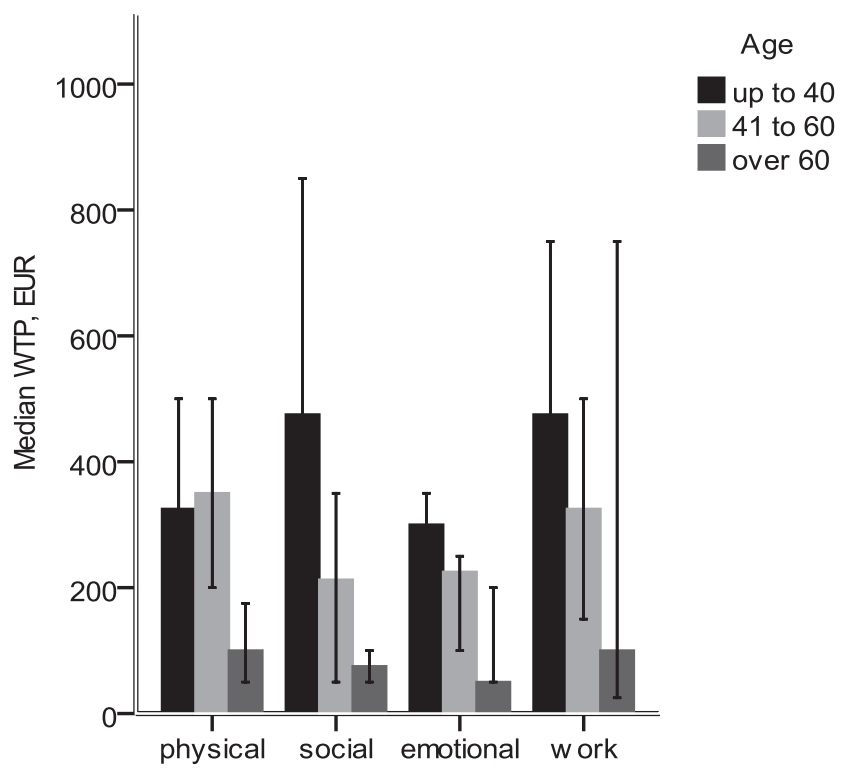

Figure 1. Median WTP by age in top affected domains (the vertical lines present $95 \%$ confidence intervals). 
Table 4. Spearman correlation coefficients between reported domains' WTP, DLQI and Euro Qol scores

\begin{tabular}{|c|c|c|c|c|c|c|c|c|c|c|}
\hline & $\begin{array}{l}\text { Inti- } \\
\text { macy }\end{array}$ & $\begin{array}{l}\text { Physical } \\
\text { comfort }\end{array}$ & $\begin{array}{l}\text { Self- } \\
\text { care }\end{array}$ & Work & $\begin{array}{l}\text { Concen- } \\
\text { tration }\end{array}$ & $\begin{array}{c}\text { Emotional } \\
\text { health }\end{array}$ & $\begin{array}{l}\text { Social } \\
\text { comfort }\end{array}$ & Sleep & DLQI & Euro Qol \\
\hline Intimacy & 1.000 & $0.514^{*}$ & $1.000^{* *}$ & 0.211 & -0.590 & 0.041 & 0.180 & 0.266 & -0.021 & -0.063 \\
\hline Sig. (2-tailed) & & 0.029 & & 0.510 & 0.095 & 0.884 & 0.474 & 0.525 & 0.928 & 0.785 \\
\hline Physical & & 1.000 & 0.085 & $0.431^{*}$ & $0.511^{*}$ & $0.583^{* *}$ & $0.530^{* *}$ & 0.402 & 0.070 & 0.125 \\
\hline Sig. (2-tailed) & & & 0.828 & 0.035 & 0.025 & 0.000 & 0.001 & 0.051 & 0.642 & 0.409 \\
\hline Self-care & & & 1.000 & 0.647 & 0.257 & 0.228 & 0.029 & $0.883^{*}$ & 0.553 & -0.034 \\
\hline Sig. (2-tailed) & & & & 0.083 & 0.623 & 0.588 & 0.957 & 0.020 & 0.122 & 0.932 \\
\hline Work & & & & 1.000 & $0.563^{*}$ & 0.389 & 0.318 & $0.852^{* *}$ & 0.015 & -0.123 \\
\hline Sig. (2-tailed) & & & & & 0.036 & 0.082 & 0.185 & 0.000 & 0.941 & 0.540 \\
\hline Concentration & & & & & 1.000 & $0.622^{* *}$ & $0.610^{* *}$ & $0.602^{*}$ & 0.074 & -0.050 \\
\hline Sig. (2-tailed) & & & & & & 0.006 & 0.009 & 0.017 & 0.751 & 0.829 \\
\hline Emotional & & & & & & 1.000 & $0.712^{* *}$ & $0.585^{* *}$ & -0.095 & -0.074 \\
\hline Sig. (2-tailed) & & & & & & & 0.000 & 0.009 & 0.577 & 0.665 \\
\hline Social & & & & & & & 1.000 & $0.667^{* *}$ & 0.137 & 0.106 \\
\hline Sig. (2-tailed) & & & & & & & & 0.002 & 0.411 & 0.527 \\
\hline Sleep & & & & & & & & 1.000 & -0.235 & -0.296 \\
\hline Sig. (2-tailed) & & & & & & & & & 0.239 & 0.134 \\
\hline DLQI & & & & & & & & & 1.000 & $0.783^{* *}$ \\
\hline Sig. (2-tailed) & & & & & & & & & & 0.000 \\
\hline Euro Qol & & & & & & & & & & 1.000 \\
\hline
\end{tabular}

* Correlation is significant at the 0.05 level.

** Correlation is significant at the 0.01 level.

The psoriasis VAS scores and income groups were not related (Pearson $c^{2}=33.44$; Sig. $>0.05$ ). The distribution of VAS scores by the income groups is shown in Fig. 3. It can be seen that the patients with worst health conditions fall in the lowest income groups.

The patients' choice of method of treatment of psoriasis is worth noting. The largest proportion and number of participants $(37.3 \%$ with $95 \% \mathrm{CI}$ $[23.0 \% ; 51.6 \%], \mathrm{n}=19)$ stated preferences for the second option of systemic therapy (choice 'D',
Table 1). The second preferred choice was the thalassotherapy $(29.4 \%$ with $95 \%$ CI [ $15.9 \% ; 42.9 \%]$, $\mathrm{n}=15$ ).

The first reason for the most frequent choice was the place of treatment $(54.9 \%$ with $95 \%$ CI $[40.3 \% ; 69.5 \%])$ and the second cause was the effectiveness of treatment $(43.1 \%$ with $95 \%$ CI $[28.5 \% ; 57.7 \%])$.

Among those who chose medication prevailed those who ranked 'physical comfort' $(n=7)$ as the most impacted domain followed by the 'ability to 
Table 5. Ranking of domains among three studies by their affection from the disease

\begin{tabular}{lll}
\hline Delfino et al. & Hu et al. & This study \\
\hline $\begin{array}{l}\text { Physical } \\
\text { comfort }\end{array}$ & $\begin{array}{l}\text { Physical } \\
\text { comfort }\end{array}$ & $\begin{array}{l}\text { Physical } \\
\text { comfort }\end{array}$ \\
$\begin{array}{l}\text { Social } \\
\text { comfort }\end{array}$ & $\begin{array}{l}\text { Emotional } \\
\text { health }\end{array}$ & $\begin{array}{l}\text { Social } \\
\text { comfort }\end{array}$ \\
$\begin{array}{l}\text { Emotional } \\
\text { health }\end{array}$ & Sleep & $\begin{array}{l}\text { Emotional } \\
\text { health }\end{array}$ \\
Self-care & Work & Work \\
Intimacy & Social comfort & Sleep \\
Sleep & Self-care & Concentration \\
Work & Intimacy & Intimacy \\
Concentration & Concentration & Self-care \\
\hline
\end{tabular}

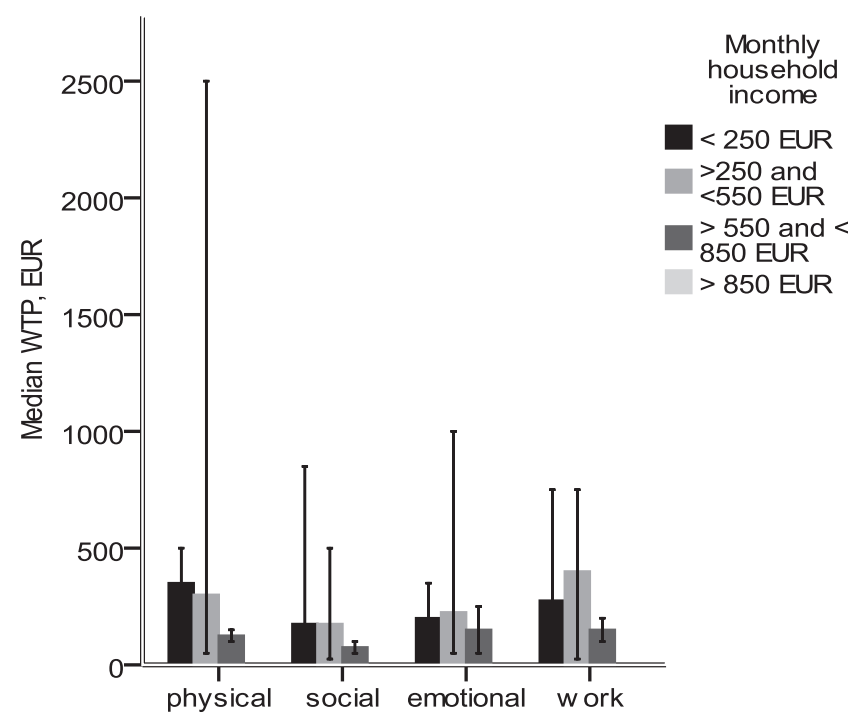

Figure 2. Median WTP by income in top affected domains (the vertical lines present 95\% confidence intervals).

work' $(n=4)$. The results for the thalassotherapy were as follows: 'social comfort' $(n=4)$; 'ability to work' $(n=3)$ and 'sleep' $(n=3)$.

\section{DISCUSSION}

We consider a focus of the discussion whether and how the results of this particular study relate to other studies in psoriasis to help us draw some conclusions about the utility of tools measuring HRQOL, stated preferences and WTP in Bulgaria.

The studied population in our survey differed significantly from those studied by $\mathrm{Hu}$ et al. ${ }^{13}$ and Delfino et al. ${ }^{14}$ ] by socio-demographic characteristics as age structure, education and income distribution. Our patient population was older with $37.3 \%$ people aged above 60 and $17.6 \%$ younger than 40. This fact causes the income level differences among patient contingents. There is an expressive contrast of patient's income distribution. In the higher two levels of the income in the presented study felt only $15.7 \%$ of the patients while the previous studies these weights were respectively $55 \%$ and $65 \% .^{13,14}$

However our results support the findings of the other pilot studies about the top four domains impacted by the disease (Table 5).

Our results related to the effect on and ranking of domains are similar to those reported by Delfino et al. It might be due to the severity of the psoriasis in our and Delfino's population. We ave to take in consideration that the Hu's sample ncludes patient with arthritis complication with igher VAS measures (Table 2). The three least iffected domains were also ranked similarly, sugresting that HRQOL domains used were reliable neasures in patients with psoriasis regardless of ther characteristics.

The reported median WTP is higher in top Iffected domains. This trend is expressed in presint study similarly to the previous findings. ${ }^{13,14}$ $\mathrm{Ne}$ found some differences in correlations across NTP reported in each domain between the referint studies. In the population of $\mathrm{Hu}$ et al. the spearman's correlation coefficients of WTP across lomains were greater than 0.5 and were statistially significant. ${ }^{13}$ In our correlation matrix we had 12 statistically insignificant associations with values up to 0.5 . However the empirical relations between the 'sleep', 'self-care', 'work' and 'social comfort' domains were confirmed. Another fact which is discussible is the correlation between DLQI, Euro Qol scores and WTP domains. From this point of view the results from the present study contrast to the other which confirmed close relation between DLQI indices and WTP for cure of skin diseases. ${ }^{15,16}$

In spite of the chi square statistics we see another interesting trend - the severity of illness is associated with lower income groups (Fig. 1). In the 


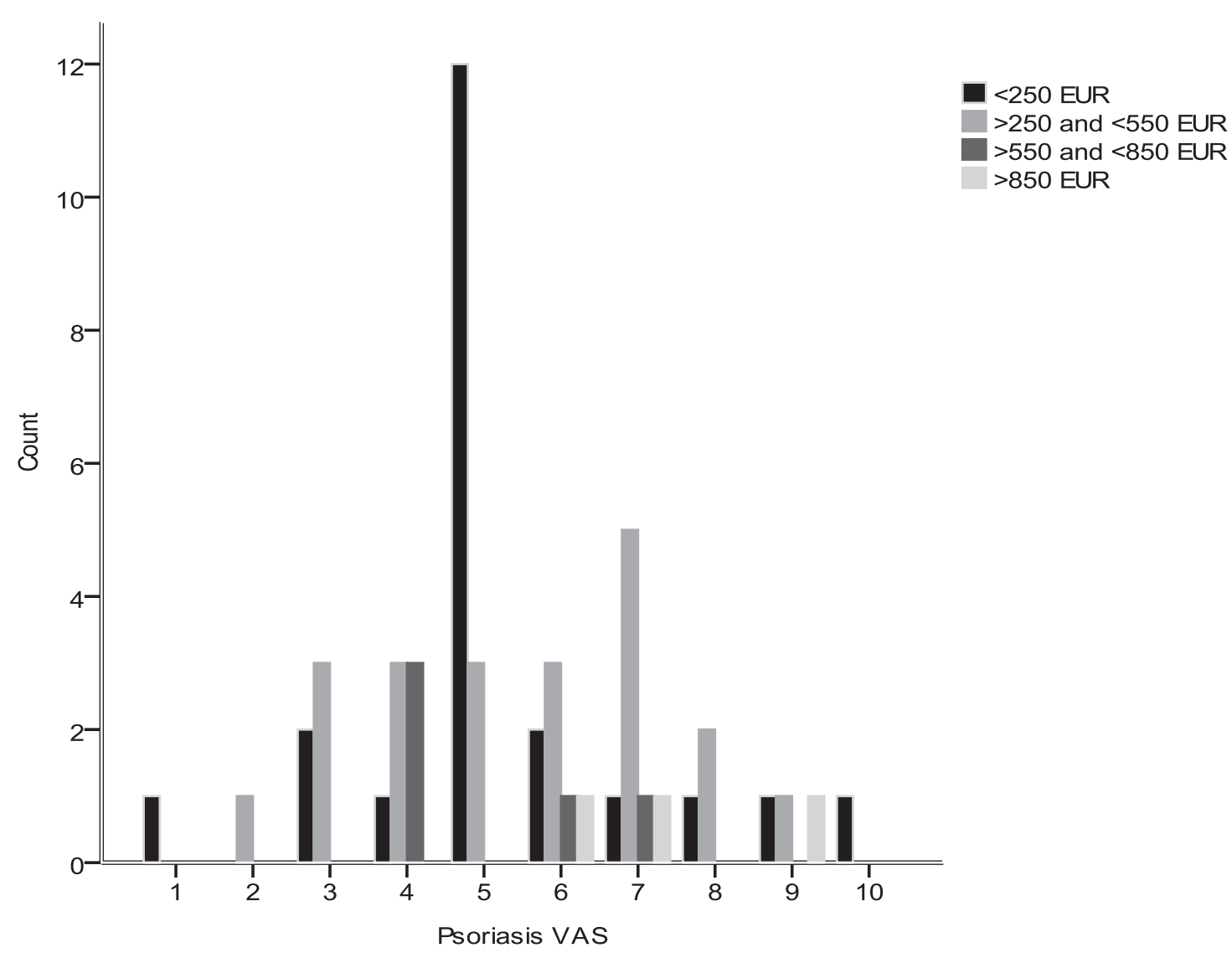

Figure 3. Distribution of patients by income and severity of disease.

lower five VAS levels fall $29 \%$ of the interviewees with monthly income less than 250 EUR and 20\% with income less than 550 EUR. If we take into consideration that for some of the most affected domains the median WTP achieves its maximum in the lower income groups then we could suppose that the patients with less income have worse health conditions and in the same time they report some of the highest WTP for cure. This trend causes noticeable differences of financial burden assessment of psoriasis among patients from different income groups and health state and this is similar to the findings of previously conducted studies. ${ }^{14,17}$

\section{CONCLUSIONS}

The results from the present study are quite similar to the previously presented by Delfino et al. and $\mathrm{Hu}$ et al. However, there are some differences concerning the correlation between household income levels and stated WTP. The absence of statistically confirmed positive correlation between income levels and WTP in our study was most probably due to the chronic nature of psoriasis and its strong impact on patients' quality of life or to the small sample.

Our findings strongly support the data from other studies that the instrument based on the assessment of WTP stated preferences for eight HRQOL domains is a good and reliable measure for evaluation of the individual burden of psoriasis. This could encourage further studies of the instrument in the purpose of modelling the stated preferences, the demand and the WTP of patients with psoriasis.

FUNDING: This study was funded by Medical University of Plovdiv with grand No 15/2012.

LIMITATIONS: The results of this study are affected by factors with restrictive sense like small sample and relatively high proportion of old patients with low household income.

INFORMED CONSENT: Informed consent was obtained from all individual participants included in the study. 


\section{ACKNOWLEDGMENTS}

The authors would like to thank Prof. Abrar Qureshi for providing us with willingness-to-pay study tool.

\section{REFERENCES}

1. Menter A, Stoff B. Psoriasis. London, UK: Manson Publishing Ltd; 2010.

2. Sarkar R, Chugh S, Bansal S. General measures and quality of life issues in psoriasis. Indian Dermatol Online J 2016;7(6):481-8.

3. Bhosle M, Kulkarni A, Feldman S, et al. Quality of life in patients with psoriasis. Health and Quality of Life Outcomes 2006;4:35.

4. Mitchel RC, Carson RT. Using surveys to value public goods: the contingent valuation method. Washington DC: Resources for the future 1989; 17-49.

5. Carson RT, Hanemann M. Contingent Valuation. In: Mäler K-G, Vincent JR, editors. Netherlands: Elsevier BV; 2005:822-920.

6. Mitchel RC, Carson RT. Using surveys to value public goods: the contingent valuation method. Washington DC: Resources for the future 1989: 88.

7. Arrow K, Solow R, Portney PR, et al. Report of the NOAA panel on contingent valuation. Federal Register 58. 1993, pp. 4601-14.

8. Smith R, Sach T. Contingent Valuation: What needs to be done? Health Economics, Policy and Law 2010;5:91-111.

9. Atanasov N, Dobrev H, Raytcheva R, et al. Contingent valuation of the patients' willingness to pay for dermatological and dental treatment. Journal of International Scientific Publications: Economy \& Business 2013;7(2):219-28.

10.Drummond MF, O'Brien BJ, Stoddart GL, et al. [Methods for the economic evaluation of health care programs.] 2nd ed. Sofia: MF; 2007:289-94 (in Bulgarian).

11. McIntosh E, Clarke PM, Frew EJ, et al, eds. Applied methods of cost-benefit analysis in health care. Oxford: Oxford University Press; 2010:127-38.

12.Edejer TT, Baltussen R, Adam T, et al, editors. Making choices in health: WHO Guide to cost-effectiveness analysis. Geneva: WHO Geneva; 2003:18.

13. Hu SW, Holt EW, Husni ME, et al. Willingness-topay stated preferences for 8 health-related qualityof-life domains in psoriatic arthritis: A Pilot Study. Semin Arthritis Rheum 2010;39(5):384-97.

14. Delfino MHE, Holt EW, Taylor CR, et al. Willingness-to-pay stated preferences for 8 health-related quality-of-life domains in psoriasis: A pilot study. $\mathbf{J}$ Am Acad Dermatol 2008;59:439-47.

15.Lundberg L, Johannesson M, Silverdahl M, et al. Quality of life, health-state utilities and willingness to pay in patients with psoriasis and atopic eczema. Br J Dermatol 1999;141(6):1067-75.

16. Radtke MA, Schäfer I, Gajur A, et al. Willingnessto-pay and quality of life in patients with vitiligo. Br J Dermatol 2009;161(1):134-9.

17. Horn E, Fox K, Patel V, et al. Association of patient reported psoriasis severity with income and employment. J Am Acad Dermatol 2007;57(6):963-71. 


\title{
Применение инструмента, основанного на восьми, связанных со здоровьем доменов качества жизни, измеряющего готовность к участию в оплате лечения псориаза
}

\author{
Христо П. Добрев ${ }^{1}$, Николай Г. Атанасов ${ }^{2}$, Донка Д. Димитрова ${ }^{2}$ \\ ${ }^{1}$ Кафедра дерматологии и венерологии, Факультет медицины, Медицинский университет - Пловдив, Пловдив, Болгария \\ 2 Кафедра менеджмента и экономики здравоохранения, Факультет общественного здоровья, Медицинский университет \\ - Пловдив, Пловдив, Болгария
}

\begin{abstract}
Адрес для корреспонденции: Николай Г. Атанасов, Кафедра менеджмента и экономики здравоохранения, Факультет общественного здоровья, Медицинский университет Пловдив, бул. „Васил Априлов“ № 15A, Пловдив, 4002, Болгария

E-mail: nik.atanasov@abv.bg Тел: +359885771262
\end{abstract}

Дата получения: 26 сентября 2016

Дата приемки: 09 марта 2017 Дата онлайн публикации: 24 апреля 2017

Дата публикации: 29 сентября 2017

Ключевые слова: готовность к участию в оплате заявленных предпочтений, псориаз, качество жизни, финансовое бремя заболевания

\section{Образец цитирования:}

Dobrev HP, Atanasov NG, Dimitrova DD. Implementation of instrument based on eight health related quality of life domains for measuring of willingness to pay for psoriasis treatment.

Folia Medica 2017;59(3):326-335. doi: 10.1515/folmed-2017-0041
Введение: Псориаз обыкновенный (ОП) - хроническое состояние кожи, которое оказывает большое влияние на качество жизни, связанное со здоровьем (KЖc3).

Цель: Целью настоящего исследования является определение влияния индивидуального бремени обыкновенного псориаза на качество жизни, связанного со здоровьем с использованием инструмента, измеряющего готовность к участию в оплате (ГкУО).

Методы: Пятьдесят одному последовательно поступившему пациенту с ОП было предложено определить при помощи визуальной аналоговой шкалы (ВАШ) состояние своего общего здоровья и здоровья, затронутого псориазом и было проведено собеседование касательно 8 доменов (физический, эмоциональный, сон, работа, социальный, забота о себе, близость и концентрация) КЖсЗ и ГкУО возможного лечения по каждому домену. Были заданы также два дополнительных вопроса, предлагающих 6 альтернативных возможностей терапии. Анализ проведён с использованием описательной и частотной статистики, тестов Манна-Уитни и Крускал-Уоллиса.

Результаты: Приоритет доменов был установлен в следующей последовательности: физический комфорт(90\%), социальный комфорт (77\%), эмоциональное здоровье (75\%) и работа (53\%). Были установлены следующие тенденции, связанные с ГкУО в отношении первых четырёх доменов, в среднем ГкУО оказалось ниболее высоким в отношении доменов на первых местах; пациенты молодого возраста были готовы к участию в оплате в большей степени по сравнению с пациентами пожилого возраста; наиболее высокое среднее значение ГкУО было установлено в групппе с наиболее низкими доходами; наиболее высокое среднее значение ГкУО связывается с более низкими результатом по ВАШ в отношении здоровья, затронутого псориазом. Наибольшая часть и количество пациентов $(37.3 \%, \mathrm{n}=19)$ заявили свои предпочтения в пользу системного лечения. На втором месте среди предпочитаемых методов лечения была поставлена талассотерапия (29.4\%, n=15).

Заключения: Настоятельно рекомендуем полезность и надёжность инструмента, основанного на оценке ГкУО в отношении восьми доменов КЖсЗ для оценки индивидуального бремени псориаза. 